\title{
Diniyah Education Curriculum Integration in Learning State Primary School 2 Sedayulawas Brondong Lamongan
}

\author{
Al-Hidayah ${ }^{1}$, \\ Akhtim Wahyuni ${ }^{2}$ \\ Master of Islamic Education Management, \\ Universitas Muhammadiyah Sidoarjo, Indonesia \\ Alhidayahagung47@gmail.com,
awahyuni@umsida.ac.id

\begin{abstract}
Research aims to know how this process of implementation of integrated curriculum in sd negeri 2 sedayulawas. Using this research qualitative research, research in the field ie. Data collection using interview, observation and documentation. The analysis data analysis using descriptive. Results indicate that the concept of curriculum integration of applied in sd state 2 sedayulawas formulated with: concept vision, mission and purpose, integration curriculum, planning curriculum, the implementation of curriculum, rational interactive design of curriculum model, as for the procedural including planning model deductive.
\end{abstract}

Keywords: Integrated curriculum, religious education, and learning.

\section{INTRODUCTION}

Education and learning is a process that is more complex activity, due to the development of science and technology in the era of globalization. Education in schools need to be held with the optimal producing graduates with high quality. Improved quality is the core mission of education so that students are expected to become children prodoktif, and quality. The statement in accordance with Law No. 20 of 2003 states, the National Education System is a national education aims to develop human potential in order to become peseta learners noble, healthy, knowledgeable, skilled, creative and devoted and faithful to God Almighty, and become citizens of a democratic and accountable. [1]

Human Resources Tangguh and quality is the challenge of education is very heavy, because education should be able to build and establish karkter, and education not only provides knowledge of the most cutting-edge, but should be able to build learners, so that they can develop their potential and discover the purpose of life.

Diniyah Madrasah education agency bercirikhas namely Islam and is the oldest institution in Indonesia, whose existence has been known since the colonial era and had a stake big enough to fight for and achieve the nation Indonesia. Madrasah Diniyah namely: the type of shape that only educational institutions teach religious sciences (Fiqh, Hadith Qur'an, Aqeedah). Islamic religious education in relation to the development of the human person is an important and fundamental issue. Madrasah diniyah is essentially a building supervision on the basis of morality, where it can be proved from the fact that the order of life of the nation and in every field, not determined solely by the laws of positive,

Prior research [2] the title of the implementation of the integrated curriculum development, with some of the literature, namely, the concept of integrated curriculum in MI Ma'arif NU Pucang Sidoarjo. Chichi Aisyatud Da'watiz Zahroh (2016), the title diniyah takmiliyah madrosah models integrated in public primary schools[2].

Based on the review of the research work above, this study discusses the curriculum integration, namely the integration between curriculum Kemendikbud and curriculum MORA conducted by the State Elementary School 2 Sedayulawas, in terms of the integration of learning hours are learning hours diniyah integrated into hours of formal learning and research examine the problems and focus on the concept and implementation of integrated curriculum in Elementary School 2 Sedayulawas.

\section{MAIN PART}

The method used in this research is descriptive qualitative research method, the research that produces descriptive data in the form of words written or spoken of behavior diamati.Menurut Whitney (1960: 160) is a descriptive method with the fact-finding correct interpretation. Descriptive research is research that seeks to describe a phenomenon, events, events that occur in the present. (Sujana and Ibrahim, 1989: 65). Descriptive research focus on solving the actual problems as they are at the time of research conducted. In education, more descriptive research to solving practical function of the development of science. Researchers trying to 
photograph the events and incidents that became the center of attention, then depict or describe it as such, so that the utilization of research findings are valid at the same time are not necessarily relevant when used for the future. Because it does not always require their hypotheses. Does not require any treatment or manipulation of variables, because the symptoms and the event has existed and researchers lived describing it.

Types of research. Research conducted both qualitative researcher, the researchers collected data were dilapanagan (Field Research) with a case study approach, the research conducted intensively, detail and depth to the agency in this case SD Negeri 2 Sedayulawas-Brondong -Lamongan. Using descriptive method, the method of this study is a qualitative research method research that produces descriptive data in the form of words written or oral, and behavior were observed [3].

Types and Sources of Data. Data obtained in the form of qualitative data. The culprit in this study are: people who carry out the integrated curriculum, and the people who really understand and who do the activities and pristiwa happened at the school, with a month long study. Source of research data are:

1. Primary Data Sources. The primary data source in the form of data words and actions concerning (a) the information integrated curriculum developed by the SD School 2 Sedayulawas-Brondong-Lamongan obtained through interviews with Quality Assurance, Principal, Waka Curriculum, Teacher of subjects. (B) data on pembelajaan process in the classroom by teachers through observation, (c) the following documents drafted a model syllabus, acquired through technical documentation and other data that aims to obtain data directly from the first party.

2. Secondary Data Sources. Secondary data source that the source of the data obtained from books, reference materials as well as all the study results support and enrich the primary data source. From this research, the information obtained from the SD Negeri 2 Sedayulawas- Brondong-Lamongan, also of several documents such as letters, diaries, notes specific to the SD Negeri 2 Sedayulawas-Brondong-Lamongan.

Method of collecting data. This study requires one month to collect data. And data used by the researchers to collect data via several methods:

1)Interview. Interviews are used as a tool to collect data. If researchers want to know the things of the respondents deeper. In doing question and answer, can occur between researcher and respondent to interview in interactive or unilaterally only example of research only. [4]Data can be collected from this technique are: 1) The process of curriculum integration, a reference that support the curriculum integration processes, procedures pencanaan curriculum, program of activities. 2) Model curriculum. 3) Form of learning and evaluation carried out for example the implementation of an integrated curriculum

2) Observasi.Observasi ie activities carried out directly in the field to collect data or information obtained, there are several kinds of observation, such as participatory observation, observation overtly or covertly and unstructured observation[5]. For this study, researchers conducted observations of passive participation, passive participation observation that the researcher comes to the means of the observed activity, but does not get involved in that activity. In this case, researchers conducted observations in the learning process in the classroom, that is when learning takes place, and the geographical location of the school, so that the data obtained from this method are: 1) Form of management learning in the classroom. 2) Learning method used.

3)Documentation. From the interview along with the observation could be more credible if supported by documentary evidence, in this method can be used to view the event and then, so in this study, how the documentation will be used to examine the official documents relating to the implementation of the integrated curriculum at SD Negeri 2 Sedayulawas-Brondong-Lamongan. In an official document that is done by using the documentation of which is meeting minutes books, yearbooks, official letters, the list of employees and teachers, Program is working and others. Data collected from the way of documentation, namely: 1) .Profil school, organizational structure trintegrasi curriculum. 2) The study, covering the syllabus and RPP.3). Means and perasarana as well as input and output data of participants

Data analysis method. Data analysis methods used in this research is descriptive analytic Miles and Huberman interactive particular by analyzing data obtained by giving sufficient explanation and understanding to be an overview of the implementation of the integrated curriculum at primary school 2-Brondong Sedayulawas-Lamongan. To analyze the data the researchers used the steps of: coverin[6]

1) Reviewing all good dataSetelah all the data gathered from interviews, observation and documentation, and the data was seen, studied and studied, to be understood thoroughly, and then developed and widely translated from bemacam kinds of circumstances and of various phenomena in the field were obtained.

2) Classification. In this stage the researchers grouped the answers and data that is then regrouped according to the indicators predefined. 
3) Interpretation. The interpretation is the final step in analyzing the data, at this stage given the data interpretation and investigators immediately enrich data analysis information through comparative analysis (comparison) for not eliminate the original context, and the result is a presentation on the situation and the symptoms of exposure in the form of a narrative.

\section{RESULTS}

Curriculum integration is not a term of its own, but is part of the curriculum concept model. Curriculum integration is the concept of a curriculum that is not only a plan, which is simply an arrangement of material and part of the planning, but it has become a model curriculum concept is intact and has a complete design. Curriculum integration is an attempt reconstruction of the existing curriculum.

The process of the integrated curriculum that is: the process of curriculum integration is the concept of curriculum model is intact and has a complete design. The process of curriculum integration in SD Negeri 2 Sedayulawas namely: curriculum Ministry of Education and Culture and the Ministry of Religious curriculum, curriculum integration of the Ministry of Education and Culture and the Ministry of Religious Affairs since diniyah education program programmed and implemented in SD Negeri 2 Sedayulawas. The process of curriculum integration in SD Negeri 2 Sedayulawas, namely:

Integrated curriculum planning. Integrated curriculum planning when classified on interactive curriculum rational planning model, which saw rationality as the demands of an agreement between the different opinions expressed are sourced from various disciplines of subjects, which does not follow a logical sequence for spiked on the topic or theme of the issue [7].

Interactive model of this rational, rationality assumption emphasis on curriculum flexibility response and prioritize initiatives at the school level or local level. But procedurally integrated curriculum including deductive rational planning model, which focuses on logic in designing the program curriculum and specifications Focusing on the vision, mission and goals.

The concept of integrated curriculum, namely: integrated curriculum (curriculum integration). As for the integrated namely curriculum Ministry of Education and culture (Kemendikbud) and the curriculum of the Ministry of religion (MORA) model integrated curriculum That model developed is a model of fragmented (fragment), curriculum fragmented is the curriculum that were understood as curriculum subjects are separate from each other ( separated subject curriculum) in which the subjects are fragmentary and less is interrelated with other subjects[8]. Or model of fragmented characterized by the integration characteristic which is limited to one subject. For more details, illustrated in the following chart.

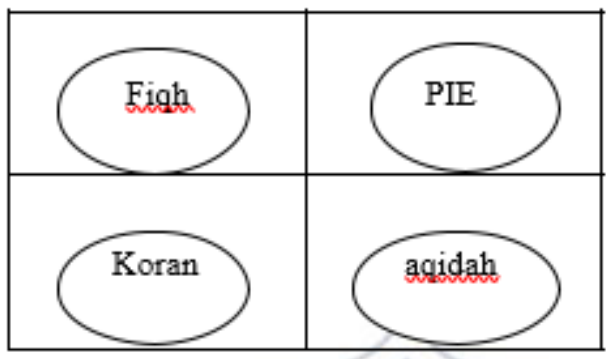

Picture. 4:14 Model Fragmented

Fragmented models namely the composition of the traditional curriculum that separate the various subjects are taught separately and there is absolutely no attempt to connect or combine these lessons, and a conventional learning models (generally) are separate subjects. It is learned that students without connecting the meaningfulness and linkages between the lessons with other subjects. Each subject is taught by a different teacher. Each subject has its own ranahnya and no effort to unite them.

Implementation of Integrated Curriculum. Curriculum terintegasi which is a blend of curriculum Kemendikbud and MORA, curriculum integration is the integration between general science and religion, to build general knowledge with the underlying science of religion so that there is no dichotomy general science and religious studies, students learn not only academically, but also learning diniyah in directing pesrta students for spirited character, discipline and morals, in the implementation of the curriculum is realized in the learning process, in accordance with the principles and demands of the curriculum, through integrated learning for learners to gain experience directly, so that can add strength to accept, store and producing impressions about things that learn it.

In the implementation of the integrated curriculum is through, stages, forms management, teaching methods Curriculum Evaluation Trintegrasi. Education policies is a reference of the evaluation process carried out in public schools. Curriculum evaluation refers to the following principles: (1) evaluation refers to the destination (2) evaluation is comprehensive and (3) evaluation carried objectively. Implementation of an integrated curriculum evaluation. Assessment of students achieving basic competencies is based on indicators. Assessment is done by 
using a test and non-test in the form of written or oral, observation of performance, attitude measurement, assessment work duties and / or products, the use of portfolio and self-assessment.

Assessment by teachers without a test based on a portfolio where the teacher notes and describing of students, namely: What are observable reports from fellow teachers and school officials, reports from parents of students and students themselves. Rate teachers based on the task or learning experiences that must be passed the student with a written report, namely: home learning task well done individually or in groups,

From the results of evaluations for consideration and a measure of success of the application of trintegrasi appropriate curriculum planning and institutional objectives aspired. The successful implementation of an integrated curriculum provides a positive impact on learners, in terms of achievement, moral and creativity (skills).

From the discussion, it can be summed up as follows:

\section{CONCLUTION}

1. Diniyah education curriculum integration process is a concept that uses integrated trintegrasi curriculum vitae, which integrates curriculum Ministry of Education and Culture (Kemendikbud) and the curriculum of the Ministry of Religious Affairs (MORA). With reference to the concept of vision and mission.

2. Trintegrasiyang curriculum planning to do, in substantive including curriculum planning interactive model of rational, while procedurally including deductive model of rational planning. Model Robin Fogarty embraced the theory of integration.

3. Implementation of integrated curriculum based on the documents integrated curriculum, implementation of integrated curriculum materialized during the hours of learning with their respective fields of study, the process pembelajaranya taught separately and there is absolutely no attempt to merge the meaningfulness and keterkaiatan between one lessons with other subjects. Integrated curriculum emphasizes the functional integration between cognitive, effective and psychomotor in its evaluation.

\section{REFERENCES}

1. "Law No. 20 of 2003 on National Education System," vol. 1. .

2. E. Yulita, "Implementation of Integrated Curriculum Development in Sidoarjo Pucang MI Ma'arif NU." .

3. L. J. Moelong, Qualitative Research Methodology. Bandung: PT. Youth Rosdakarya.

4. Sukardi, Competence Education Research Methodology and Practice. Jakarta: Earth Literacy.

5. Educational Research Methods Quantitative Approach, Qualitative, R \& D. Bandung: Alfabeta.

6. A. Prastowo, Qualitative Research Methods in the Study Design Perspectives. Yogakarta: Ar-Ruzz Media.

7. Oemar Hamalik, Management of curriculum development, vol. akarya,. Bandung: PT. Teen Rosd.

8. A. H. Hernawan and etal, "Desekularisasi Thought: Learning integrated in SD, (Bantam; the Open University-Kemenrist, technology and higher education." . 